\title{
Implikasi Unggulan Perguruan Tinggi Pada Aktivitas Ekonomi Daerah
}

\author{
Syaiful Anwar. AB \\ Universitas Bengkulu
}

\begin{abstract}
Abstrak: Tujuan penelitian ini mengetahui isi, implementasi dan kinerja kebijakan Universitas Bengkulu dalam peningkatan kualitas, relevansi dan dayasaing serta implikasinya pada kegiatan ekonomi daerah. Data penelitian adalah kebijakan Universitas Bengkulu sejak 2006 sampai 2008. Indikasi temuan: 1) ada konsistensi antara kebijakan nasional dan kebijakan Universitas Bengkulu dalam hal dayasaing, desentralisasi, otonomi dan kesehatan organisasi dan 2) peningkatan kualitas, relevansi dan unggulan Universitas Bengkulu, dapat mendorong aktivitas ekonomi daerah, dunia usaha dan dunia kerja. Selanjutnya, perguruan tinggi dapat mencapai kualitas, relevansi dan unggul dengan menerapkan sistim manajemen terpadu, berinovasi serta tanggap terhadap isu-isu berkelanjutan
\end{abstract}

Kata kunci: unggulan dan ekonomi daerah

\begin{abstract}
The objective of this research is to study the content, implementation, and policy performance of quality, relevance and core competitiveness of Bengkulu University. The data of this research is policies of Bengkulu University since 2006 up to 2008. The findings indicate: 1) consistency between the National policies and the policies of Bengkulu University in regard to competitiveness, decentralization, outonomy, and health of the organization and 2) improved quality, relevance and core competitiveness of Bengkulu University in driving regional economic activities, enterprise and working athmosphere; Therefore, in a higher education that wishing to reach quality, relevancy, core competitiveness should apply total quality management system and has innovation, and care for the current issues continously.
\end{abstract}

Key words: core competitiveness and regional economics

\section{Pendahuluan}

Sejarah perkembangan perguruan tinggi di Indonesia dimulai pada tahun 1920, di mana pada tahun tersebut berdiri Technische Hoogeschool, THS Bandung, sekarang ITB. Lembaga pendidikan tinggi di dunia setelah Akademi Plato pada empat abad sebelum masehi adalah Bologna pada abad ke 11 Italia, Paris (Perancis) dan Oxford di Inggris pada abad ke 12. Setelah periode ini perguruan tinggi yang bentuk kelembagaannya menjadi universitas telah mengalami suatu evolusi yang demikian panjang dari sekedar penghasil lulusan.

Pada tahun 1809 dengan pionirnya Von Hunbolt (Jerman) universitas berkembang sebagai lembaga riset, dan pada 1862 menjadi lembaga pengabdi pada masyarakat dengan adanya gerakan Land Grant oleh Presiden Abraham Lincoln melalui Morril Act .
Setelah periode ini, khususnya di AS dan Eropa Barat (Inggris, Jerman, dan Perancis), di samping sebagai lembaga pendidikan, universitas adalah juga lembaga riset dan lembaga pengabdi pada masyarakat. Karena itu, penerapan Tri Darma Perguruan Tinggi adalah bentuk mutakhir universitas di dunia (Soedijarto,2008)

Perkembangan perguruan tinggi di Indonesia saat ini sangat pesat, baik jumlah maupun kualitasnya. Sampai akhir tahun 2008 jumlah perguruan tinggi lebih sekita 3600 buah. Perguruan tinggi negeri (PTN) sebanyak 83 buah yang tersebar di seluruh wilayah Indonesia. PTN Indonesia saat ini sangat beraneka ragam mutunya. Sementara ukuran mutu itu sendiri belum jelas keragaannya. Ada perguruan tinggi yang telah meroket tinggi dan bahkan telah ditetapkan oleh pemerintah sebagai perguruan tinggi Badan 
Hukum Milik Negara (BHMN) sebagai ujud ukuran mutu perguruan tinggi di Indonesia, padahal seharusnya tidak demikian ukuran mutu senyatanya.

Dalam memimpin organisasi seorang pemimpin perguruan tinggi harus mampu menggerakkan kekuatan organisasi yang dimilikinya untuk bersaing dalam industri yang sama. Kekuatan organisasi ini harus menjadi kekuatan daya saing (Competitiveness Strengths) dalam memenangkan persaingan. Menurut Brojonegoro, (2004) untuk meningkatkan daya saing dan mutu perguruan tinggi maka perlu diupayakan adanya indikator kinerja perguruan tinggi, untuk sementara dapat dinyatakan dalam: 1) kuantitas dan kualitas serta relevansi lulusan; 2) kuantitas dan kualitas serta relevansi penelitian dan pengembangan; dan 3) kuantitas dan kualitas, dan relevansi kegiatan pengabdian pada masyarakat.

Disadari, bahwa dengan keanekaragaman tentu mengandung pula kesenjangan-kesenjangan baik ekonomi, sosial budaya, hukum dan kesetaraan lainnya. Persoalan yang menarik adalah terjadi kesenjangan yang luar biasa pada dunia pendidikan. Kesenjangan terjadi di banyak aspek, seperti aspek pemerataan, aspek kesempatan, aspek mutu dan relevansi hasil-hasil pendidikan itu sendiri (Tampubolon, 2001).

Evolusi kebijakan pengembangan pendidikan tinggi dimulai dengan Keputusan Menteri Pendidikan dan Kebudayaan tentang Kebijaksanaan Dasar Pengembangan Pendidikan Tinggi (KDPPT) pada tahun 1975. Keputusan tersebut memuat ikhwal tujuan pengembangan, peran dan fungsi pendidikan tinggi, dasar arah pembinaan kelembagaan pendidikan tinggi, serta pembiayaan dan alokasi anggaran.

Kemudian, Direktorat Jendral Pendidikan Tinggi (Dirjen Dikti) meluncurkan program Kerangka Pengembangan Pendidikan Tinggi Jangka Panjang tahap pertama (KPPTJP 19751985) dengan isu-isu yang ditekankan adalah pemerataan kesempatan memperoleh pendidikan tinggi. Pemerataan yang dimaksud adalah pemerataan kesempatan memperoleh pendidikan tinggi dan pemerataan geografis. Pemerataan kesempatan terutama bagi penduduk usia 18 24 tahun, dan pemerataan geografis ialah penyebaran perguruan tinggi di Propinsi.
Pada periode 1996-2005 kembali Dirjen Dikti memperbaharui Kerangka Pengembangan Pendidikan Tinggi Jangka Panjang (KPPTJP Tahap II) dengan variabel yang didorong adalah peningkatan mutu, leadership, keterbukaan, pertanggungjawaban, kerja sama tim, keberlanjutan, kepemimpinan, efisiensi, relevansi, otonomi kelembagaan, dan tanggap terhadap perubahan.

Pada dekade berikutnya, yaitu tahun 20032010 Dirjen Dikti mengeluarkan Strategi Jangka Panjang Pendidikan Tinggi yang dikenal dengan HELTS - DIKTI 2003-2010. Dimensi yang hendak ditingkatkan adalah Daya Saing Bangsa, Desentralisasi dan Otonomi Perguruan Tinggi serta Kesehatan Organisasi Perguruan Tinggi. Secara praktis, di perguruan tinggi diimplementasikan dalam program-program peningkatan pemerataan, perluasan akses pendidikan, penguatan tata kelola, dan pencitraan publik.

Berbicara peningkatan mutu maka tidak akan terlepas dengan rencana strategis perguruan tinggi masing-masing. Artinya keanekaragaman potensi dan sumber daya yang dimiliki perguruan tinggi di Indonesia diharapkan adanya sinergi pelaksanaan perguruan tinggi. Sinergi yang diharapkan muncul adalah adanya partisipasi masyarakat terutama dunia usaha dan dunia industri dalam mempercepat peningkatan mutu output perguruan tinggi.

Peningkatan mutu suatu perguruan tinggi akan nampak pada penghayatan dan pengamalan nilai-nilai yang bersifat universal, humanisme yang meliputi keteguhan iman dan taqwa serta berakhlak mulia, etika dan berwawasan kebangsaan yang tinggi, kepribadian yang tangguh, dan mandiri. Selanjutnya, peningkatan mutu terlihat pada pencapaian kecakapan akademik dan nonakademik lebih tinggi yang memungkinkan lulusan dapat proaktif terhadap perubahan masyarakat dalam berbagai bidang baik pada tingkat lokal, nasional maupun internasional (Tampubolon, 2001).

Perguruan tinggi di Indonesia, termasuk Universitas Bengkulu menghadapi tantangan yang tidak kecil. Tantangan terbesar yang dihadapi adalah terjadi gelombang globalisasi ekonomi, informasi dan komunikasi serta perkembangan teknologi yang begitu cepat. Kondisi ini 
mengharuskan perguruan tinggi melakukan perubahan-perubahan manajerial yang mendasar, terutama penetapan unggulan sebagai daya tarik dan daya dorong kegiatan ekonomi daerah.

\section{Perumusan Masalah}

Universitas Bengkulu merupakan perguruan tinggi yang dinilai telah banyak menerima berbagai macam hibah peningkatan mutu perguruan tinggi dari Dirjen Dikti, sehingga didorong menuju perguruan tinggi bermutu dan menjadi penggerak pembangunan di daerah, regional dan nasional. Berangkat dari kenyataan ini maka dirumuskan permasalahan penelitian ini sebagai berikut: 1) Bagaimana isi kebijakan Universitas Bengkulu dalam peningkatan aktivitas ekonomi daerah, regional dan nasional? 2) Bagaimana implementasi kebijakan unggulan Universitas Bengkulu, sebagai pendorong dan penggerak pembangunan di Daerah di era otonomi Daerah? dan 3) Bagaimana hasil kebijakan unggulan di Universitas Bengkulu.

Tujuan Penelitian ini dimaksudkan untuk: 1) Mengetahui bagaimana isi kebijakan Universitas Bengkulu dalam peningkatan aktivitas ekonomi daerah, regional dan nasional? 2) Mengetahui bagaimana implementasi kebijakan unggulan Universitas Bengkulu, sebagai pendorong dan penggerak pembangunan di Daerah di era otonomi Daerah? dan 3) Mengetahui bagaimana hasil Kebijakan unggulan di Universitas Bengkulu.

\section{Kajian Literatur}

\section{Manajemen Perguruan Tinggi di Indonesia}

Perguruan tinggi di Indonesia adalah organisasi sosial atau nirlaba. Organisasi merupakan wadah orang-orang untuk berinteraksi dan beraktivitas dalam rangka mencapai tujuan yang telah ditetapkan sebelumnya. Sebagai wadah tempat berhimpun orang-orang dalam organisasi maka diperlukan pengelolaan atau manajemen.

Pengertian manajemen yang dipakai dalam tulisan ini adalah proses perencanaan, pengorganisasian, pengarahan dan pengawasan aktivitas orang-orang, sumber daya dan lingkungan dalam mencapai tujuan organisasi. Sedangkan Manajemen Pendidikan Tinggi adalah proses perencanaan, pengorganisasian, pengarahan dan pengawasan kegiatan pengajaran, penelitian, pengabdian pada masyarakat serta sumber daya untuk mencapai tujuan perguruan tinggi (Eko Indrajit, dkk, 2006)

Pendidikan tinggi dan perguruan tinggi sering dicampuradukkan pengertiannya. Untuk menjelaskan perbedaan kedua hal tersebut adanya baiknya mengutip Peraturan Pemeritah RI Nomor 60, Tahun 1999 tentang pendidikan tinggi, tujuan pendidikan tinggi adalah: a) menyiapkan peserta didik menjadi anggota masyarakat yang memiliki kemampuan akademik dan atau profesional yang dapat menerapkan, mengembangkan dan atau memperkaya khasanah ilmu pengetahuan, teknologi, dan kesenian; b) mengembangkan dan menyebarluaskan ilmu pengetahuan, teknologi, dan atau kesenian serta mengupayakan penggunaannya untuk meningkatkan taraf kehidupan masyarakat dan memperkaya kebudayaan nasional. Pendidikan tinggi adalah pendidikan pada jalur pendidikan sekolah pada jenjang yang lebih tinggi daripada pendidikan menengah di jalur pendidikan sekolah, sedangkan perguruan tinggi adalah satuan pendidikan yang menyelenggarakan pendidikan tinggi.

\section{Perubahan Organisasi}

Perguruan tinggi merupakan institusi yang memiliki peran dan posisi yang strategis dalam pencapaian tujuan pendidikan secara makro yang perlu melakukan upaya perbaikan secara terus menerus untuk mewujudkan SDM yang berkualitas (Buchari dan Ratih, 2008). Dalam konteks ini maka kepemimpinan visioner menjadi determinan penting dalam mentransformasi perubahan lingkungan strategis guna mewujudkan lingkungan perguruan tinggi yang kondusif melalui pembentukan "corporate culture" yang bermutu untuk pendidikan. Budaya organisasi adalah sebagai sistem makna bersama yang dianut oleh anggota-anggota yang membedakan organisasi itu dari organisasi-organisasi lain ( P. Robbin, 2003)

Perubahan lingkungan perguruan tinggi mempengaruhi perkembangan budaya organisasi sebagai suatu entitas. Entitas budaya suatu perguruan tinggi mencerminkan perilaku kelompok yang khas sebagai suatu kesatuan. Budaya akan mengarahkan organisasi pada kondisi-kondisi yang kondusif untuk pencapaian tujuan organisasi. Pada perguruan tinggi yang mapan dan 
mempunyai nilai mutu yang tinggi, kecenderungan budaya organisasi bersifat terbuka terhadap berbagai perubahan. Artinya, perguruan tinggi adaptif terhadap lingkungannya dan bahkan menjadi pelopor perubahan lingkungan, di mana perguruan tinggi yang bersangkutan berada.

Apakah yang mengharuskan para pengambil keputusan untuk melakukan perubahan? Faktorfaktor apakah yang mempengaruhinya? Menurut European Commission (1996) dalam Sutjipto (2000), menyebutkan tiga faktor yang merupakan penyebab perubahan drastis di dunia, yaitu internasionalisasi perdagangan, berkembangnya masyarakat informasi, serta perkembangan ilmu dan teknologi yang amat hebat. Pendidikan tinggi mempunyai andil yang besar dan sekaligus ditantang dalam menjawab perkembangan yang cepat tersebut.

Perubahan terpenting adalah perubahan budaya organisasi terhadap gaya kepemimpinan. Pilihan pendekatan gaya kepemimpinan seperti kepemimpinan kolega, birokratis, enterprise serta kooperatif. Kepemimpinan kolegial adalah yang paling ideal dan sesuai bagi perguruan tinggi (Warner, 1996)

Persoalan dalam manajemen universitas yang perlu diperhatikan adalah mengurangi konflik antara profesionalisme dan birokrasi. Jangan sampai konflik ini menghambat kerja sama dalam menghadapi persaingan. Kemampuan pengawasan dan koordinasi pimpinan perguruan tinggi amat diperlukan ( Bargh, et.al., 1996)

Perubahan-perubahan yang dihadapi perguruan tinggi menuntut respon yang tidak bersifat incremental melainkan respon yang lebih mendasar, yakni respon dengan melakukan perubahan paradigma. Perubahan paradigma juga berarti perubahan mental set dari stakeholders lembaga yang berubah itu. Perlu dicatat, bahwa dalam setiap perubahan yang cepat akibat teknologi, biasa terjadi kesenjangan antara penyikapan yang seharusnya dengan penyikapan yang riil terjadi. Hal ini terjadi karena perubahan mental set yang erat kaitannya dengan perubahan budaya itu, memerlukan waktu adopsi yang lebih panjang dibandingkan dengan perubahan teknologinya sendiri (Bargh et.al., 1996)
Perubahan orang-orang dalam organisasi mencangkup perubahan: 1) kebijakan penarikan dan seleksi; 2) kegiatan-kegiatan latihan pengembangan; 3) sistem balas jasa; 4) keterampilan kepemimpinan dan komunikasi manajerial; 5) sikap, kepercayaan, peranan dan karakteristik karyawan lainnya. Selanjutnya, perubahan pada perguruan tinggi diarahkan pada perubahan system, teaching, research, management and business matters, and changing relations with others (Chris, 2002)

Dalam Undang-Undang RI Nomor 20/2003 tentang Sistem Pendidikan Nasional Pasal 57, 58, 59, dan 60, menyebutkan bahwa pengendalian mutu atau yang dikenal juga dengan penjaminan mutu pendidikan dilaksanakan terhadap satuan pendidikan, termasuk di perguruan tinggi. Aspekaspek penjaminan mutu yang terpenting dilaksanakan adalah: 1) evaluasi peserta didik dan institusi; 2) akreditasi untuk menentukan kelayakan program dan satuan pendidikan; 3) sertifikasi untuk menunjukkan kompetensi kepada peserta didik untuk melakukan sesuatu pekerjaan. Akreditasi yang diperoleh satuan pendidikan atau program studi menyatakan nilai harkat mutu institusi yang bersangkutan. Oleh karena itu, Badan Akreditasi Nasional Perguruan Tinggi (BAN-PT, 2007) menetapkan kriteria perguruan tinggi bermutu adalah perguruan tinggi yang terakreditasi.

Standar mutu perguruan tinggi terakreditasi bila memenuhi berbagai standar di antaranya adalah standar kepemimpinan, standar kemahasiswaan, standar sumberdaya manusia, standar kurikulum, standar prasarana dan sarana, standar pendanaan, standar tata pamong, standar sistem pengelolaan, standar sistem pembelajaran, standar suasana akademik, standar sistim informasi, standar sistem jaminan mutu, standar lulusan, standar penelitian dan pengabdian pada masyarakat, dan standar program studi. Jika standar-standar yang telah ditetapkan memperoleh harkat penilaian tinggi maka terakreditasi baik perguruan tinggi yang bersangkutan.

Sehubungan dengan paradigma manajemen pendidikan tinggi yang menyangkut komponen kualitas, otonomi, akuntabilitas, akreditasi dan evaluasi, dikemukakan catatan sebagai berikut: 
kualitas merupakan sasaran yang bergerak, maka dalam setiap periode tertentu perlu ditetapkan benchmark untuk masing-masing perguruan tinggi, yang pada akhirnya menuju pada standar kualitas yang tinggi (Sutjipto, 2000). Tujuan benchmarking adalah mengidentifikasi dan menguji berbagai inovasi, serta penerapan yang terbaik untuk mengarahkan kunci keberhasilan universitas dalam proses pengembangan manajemen (Allen, 2002).

\section{Relevansi}

Penciptaan unggulan perguruan tinggi erat kaitannya dengan relevansi perguruan tinggi. Perbedaan tempat satu universitas dengan universitas lainnya seharusnya merupakan kelebihan dan unggulan masing-masing. Universitas harus mengenali karakteristik daerah di mana universitas itu berada. Dengan mengenali karakteristik daerahnya maka universitas dapat merencanakan kegiatan layanan yang tepat bagi pelanggan di sekitar universitas. Kekhasan layanan inilah yang merupakan modal universitas menciptakan unggulan.

Menurut Tilaar (2004), bahasan relevansi pendidikan tinggi di Indonesia sangatlah kompleks. Relevansi dapat diaplikasikan apabila kita mengubah pendekatan perguruan tinggi. Selama masih menganut pendekatan "Supply" maka selama itu pula relevansi tidak tercapai. Relevansi bisa diwujudkan apabila perguruan tinggi Indonesia telah bergeser pada pendekatan"Demand" artinya, program studi dibuka dan ditutup sesuai dengan permintaan pasar dan relevansi inilah yang disebut dengan relevansi kuantitatif.

Relevansi secara kurikuler menyangkut keserasian jenis, proses belajar yang dialami pelajar/mahasiswa dengan suasana dan tuntutan masyarakat yang akan dimasuki mereka" setelah meninggalkan lembaga pendidikan". Seterusnya, relevansi secara kurikuler adalah masalah pengembangan kualitas proses belajar yang memungkinkan terjadinya proses sosialisasi dan kulturalisasi segala sikap dan kemampuan yang diharapkan (Soedijarto,1993)

Kesesuaian output perguruan tinggi, berkaitan pula dengan dunia kerja itu sendiri. Dunia kerja adalah tempat di mana semua manusia mampu berkiprah untuk menemukan jati dirinya, mengembangkan kemampuan berkarier, mengaktualisasikan dirinya dalam pergaulan hidup dan mencapai nilai kehidupannya secara optimal seuai dengan kompetensi yang dibutuhkan, artinya relevansi yang dicapai adalah relevansi kualitatif.

Sejauh mana keberadaan universitas di Indonesia telah mempengaruhi percepatan pembangunan nasional?Tampaknya belum dapat diberikan jawaban yang positif. Bahkan, universitas di Indonesia, dari yang paling tua sampai yang paling muda, baik negeri maupun swasta, belum menunjukkan keinginan besar dan atau belum diberi kesempatan untuk terlibat, melibatkan diri, dan atau dilibatkan dalam memecahkan masalah-masalah yang dihadapi oleh masyarakat Indonesia (Soedijarto, 2008). Kontribusi unggulan perguruan tinggi belum kelihatan dalam menunjang pertumbuhan dan aktivitas ekonomi daerah.

\section{Metodologi}

Dalam penelitian ini pendekatan yang dipakai adalah pendekatan evaluasi formal, karena evaluasi formal menggunakan dokumen-dokumen undang-undang, dokumen-dokumen program, dan wawancara dengan pembuat kebijakan dan administrator untuk mengidentifikasi, mendefinisikan, dan menspesifikasikan tujuan dan target kebijakan.

Dalam kajian ini juga digunakan pendekatan evaluasi proses retrospektif meliputi pemantauan dan evaluasi program setelah program tersebut diterapkan untuk jangka waktu tertentu. Evaluasi proses retrospektif, yang cenderung dipusatkan pada masalah-masalah dan kendala-kendala yang terjadi selama implementasi kebijakan dan program. Evaluasi retrospektif lebih menggantungkan pada deskripsi ex post facto tentang kegiatan aktivitas program yang sedang berjalan, yang selanjutnya berhubungan dengan keluaran dan dampak.

\section{Hasil Penelitiaan dan Pembahasan Peningkatan Mutu, Relevansi dan Unggulan Perguruan tinggi}

Peningkatan mutu, relevansi, diharapkan dapat memberikan dampak bagi perwujudan eksistensi manusia dan interaksinya, sehingga dapat hidup 
bersama dalam keragaman sosial dan budaya. Selain itu, upaya peningkatan mutu dan relevansi dan penetapan unggulan perguruan tinggi dapat meningkatkan taraf hidup masyarakat serta daya saing bangsa.

Untuk meningkatkan mutu, relevansi dan daya saing, Universitas Bengkulu ( UNIB ) melaksanakan program strategis di antaranya: meningkatkan akreditasi program studi di lingkungan UNIB; melaksanakan penjaminan mutu melalui unit yang ditunjuk; pengembangan kompetensi pendidik dan tenaga kependidikan; perbaikan dan pengembangan sarana dan prasarana;perluasan pendidikan kecakapan hidup; pembentukkan kelas internasional; mendorong sivitas akademika UNIB untuk berpartisipasi dalam penelitian, publikasi, pengajuan HAKI dan pengabdian kepada masyarakat; peningkatan softskills dan lifeskills mahasiswa UNIB; pengembangan program-program unggulan baik di bidang pendidikan, penelitian maupun pengabdian pada masyarakat; pengawasan dan penjaminan mutu secara terprogram;pengembangan dosen sebagai profesi; teknologi informasi dan komunikasi dalam kegiatan tri darma perguruan tinggi (Renstra UNIB, 2006)

\section{Unggulan Perguruan tinggi}

Berbicara unggulan perguruan tinggi di Indonesia sangat sulit. Semestinya unggulan sebuah perguruan tinggi ditentukan oleh potensinya. Apakah potensi sumber daya manusia atau potensi sumber daya alam, bahkan ungulan dan kajian pokok atau program studi unggulan . Sekarang, bagaimana implementasi unggulan dapat dijadikan sebagai pendorong aktivitas ekonomi daerah? UNIB melalui Fakultas Pertanian program studi kehutanan mengembangkan Pusat Studi Gaharu. Studi tentang gaharu di Indonesia hanya ada di dua universitas, yaitu Universitas Nusa Cendana di Kupang dan Universitas Bengkulu. Dengan demikian, kajian gaharu hanya ada pada dua Universitas tersebut,. artinya jika para peneliti dan pemerhati ingin mengetahui tentang kayu gaharu dapat diperoleh di Bengkulu atau Kupang.

Penentuan unggulan dapat berdasarkan potensi sumber daya manusia dan wilayah. Setiap universitas mengembangkan satu atau beberapa program studi unggulan berdasarkan potensi sumber daya manusia dan wilayah, misalnya ITB dan UI dikembangkan Ilmu-Ilmu sains dan teknologi, karena dekat dengan Pusat Penelitian Serpong,. Universitas Airlangga dan Universitas Patimura dikembangkan ilmu-ilmu kelautan karena potensi lautnya, dan Universitas Gadjah Mada ilmu kedokteran.

Bagaimana kondisi perguruan tinggi di Indonesia? Unggulan perguruan tinggi tidak jelas dasarnya, bahkan tidak berani mengungkapkan secara eksplisit jenis unggulannya. Akibat dari fenomena ini maka perguruan tinggi tidak dapat menunjukkan perannya terhadap kegiatan ekonomi daerah. Bila dibandingkan dengan perguruan tinggi dunia, misalnya di Amerika Serikat, universitas yang ada pada negara bagian menunjukkan kekhasan tersendiri, seperti Universitas Kentucky terkenal dengan ilmu-ilmu pertanian, Universitas Texas dengan teknik dirgantara (pesawat terbang), dan Universitas Austin dengan ilmu pendidikan.

Dengan demikian, bila unggulan perguruan tinggi berdasarkan wilayah maka akan terjadi pergerakan orang (mahasiswa) ke suatu wilayah sehingga akan timbul efek dari pergerakan orangorang tersebut. Pergerakan orang tersebut membutuhkan akomodasi seperti transportasi, hotel dan penginapan, konsumsi, dan biaya hidup lainnya. Jadi, unggulan dapat menciptakan aktivitas ekonomi daerah yang dituju dan pada saat yang bersamaan perguruan tinggi berkontribusi terhadap kegiatan ekonomi di daerah.

\section{Peningkatan pengelolaan Otonomi sumber daya manusia}

Peningkatan Otonomi Pengelolaan Sumber daya

Manusia merupakan program unggulan UNIB. Saat ini kualitas tenaga pengajar S2 dan S3 berjumlah $68 \%$ dari keseluruhan tenaga pengajar. Jumlah dosen UNIB saat ini adalah 612 orang. Sumber daya manusia yang baik dapat mendukung menciptakan tata kelola yang efisien, akuntabel, dan penciptaan unggulan. Persoalan penetapan unggulan adalah domain pimpinan. Oleh karena itu, harus dibarengi dengan peningkatan etos kerja yang baik pada level pimpinan, maupun seluruh komponen yang terlibat dalam sistem tersebut, yaitu rektor, pembantu 
rektor, dekan, dan unit-unit terkecil lainnya. Selain itu, sejalan dengan perubahan paradigma pengelolaan pendidikan tinggi yang mengarah pada otonomi perguruan tinggi dalam bentuk Badan Hukum Pendidikan (BHP). Kesempatan yang diberikan pada perguruan tinggi berkreasi menentukan unggulan, arah dan masa depannya sendiri, seharusnya dimanfaatkan sebaik mungkin.

\section{Peningkatan Akuntabilitas}

Penerapan Information, Communication, Technology (ICT) akan dimanfaatkan secara optimal untuk membantu merealisasikan manajemen pendidikan yang transparan dan akuntabel. Model penerapannya dapat diwujudkan melalui media on-line yang memuat informasi dan laporan perencanaan dan pelaksanaan kebijakan kepada publik atau stakeholder pendidikan lainnya. Dengan media tersebut, partisipasi masyarakat dalam bentuk usulan, kritik, atau informasi lainnya dapat diakomodasi secara lebih mudah dan terbuka kepada pembuat kebijakan unggulan

\section{Ketrampilan Lunak (Soft Skills) melalui Mata Kuliah Wajib Universitas (MKWU)}

Upaya penciptaan unggulan lulusan, pada tahun 1995 UNIB berpeluang untuk mendapatkan Hibah peningkatan mutu akademik dari Dirjen dikti. Ketika itu, untuk mendapatkan proyek harus dibuat proposal yang memberi jaminan pada terciptanya "link and match" pendidikan tinggi di Indonesia. Dari hasil diskusi panjang maka diputuskanlah memberikan beberapa mata kuliah yang dianggap dapat menjembatani dunia kerja dengan perguruan tinggi.

Memberikan pengetahuan dasar pada keterampilan lunak bagi seluruh mahasiswa pada berbagai program studi strata satu yang ada di UNIB merupakan unggulan program. Sejak tahun 1997 maka diambil kebijakan dengan memberikan mata kuliah Pengantar Komunikasi, Kewirausahaan, Pengantar Komputer dan Bahasa Inggris, sebagai kurikulum muatan lokal. Kebijakan ini tetap dilanjutkan sampai sekarang dengan berbagai modifikasi serta perbaikan dalam proses belajar dan mengajarnya.

Pertanyaan lebih lanjut adalah bagaimana peran kebijakan ini dapat menciptakan alumni yang unggul dan memenuhi kriteria dunia kerja?
Berdasarkan Survei Litbang Tempo (30 Mei 2007) dunia kerja meminta kriteria sebagai berikut: 1) lulusannya mau bekerja keras; 2) kepercayaan dirinya tinggi; 3) mempunyai Visi ke depan; 4) bisa bekerja dalam tim; 5) memiliki kemampuan perencanaan matang 6) mampu berpikir analitis; 7) mudah beradaptasi; 8) mampu bekerja dalam tekanan; 9) cakap berbahasa Inggris; 10) mampu mengorganisir pekerjaan; 11) mampu menciptakan jaringan/komunikasi; dan 12) mampu bekerja dengan Teknologi informasi.

Perguruan tinggi yang dikenal oleh dunia kerja adalah perguruan tinggi tua, dan berada di pulau Jawa. Ternyata UNIB tidak termasuk dalam 20 perguruan tinggi tersebut. Pertanyaan adalah apa sebenarnya yang telah terjadi? Apakah Universitas Bengkulu kurang promosi atau memang alumni kurang berani bertarung di Jabodetabek? Terlepas dari hal-hal itu semua maka sebagai upaya pembaharuan kurikulum dan revitalisasi mata kuliah wajib universitas perlu dilaksanakan secara konsisten, terencana, dan terintegrasi.

Pertanyaan adalah apakah para alumni UNIB merasa bahwa pilihan pekerjaan sekarang adalah akibat dorongan pengetahuan MKWU ini? Berdasarkan telusur alumni dapat diketahui bahwa MKWU bermanfaat dan memberi makna pada alumni. Berdasarkan hasil wawancara dengan Mahyudin Sobri, Ketua Ikatan Alumni (IKAL) UNIB yang berada di Jakarta, dari 189 alumni yang berada di Jabodetabek dan bekerja pada berbagai bidang, ternyata, $85 \%$ dari alumni berkerja pada sektor nonpemerintah. Indikasi ini menunjukkan bahwa, kemandirian alumni UNIB nampak dan muncul ke permukaan.

Dari hasil wawancara dengan Pipin Oktasari, para alumni yang bekerja di perbankan, mereka menyatakan kekurangan pada kurikulum UNIB terutama untuk mata kuliah MKWU, adalah "praktik" pada laboratorium, praktik lapangan, dan magang, untuk ini perlu dicari solusi. Informasi ini merupakan masukan dalam penetapan kebijakan program KKN, praktik lapangan, dan magang bagi mahasiswa UNIB. Oleh karena itu, masih dibutuhkan pelatihan-pelatihan lunak untuk mendapatkan kemampuan-kemampuan unggulan sebagai penguatan kemampuan para alumni untuk bersaing dengan alumni perguruan tinggi 
lain yang ada di Indonesia. Pengadaan alat praktikum komputer dan Laboratarium Bahasa misalnya, sampai kapan pun tidak pernah cukup. Oleh karena itu, UNIB harus mempunyai alternatif strategi lain. Artinya, Unit Pelaksana Teknis Pusat Komputer (UPT Puskom) dan UPT. Bahasa Inggris UNIB hanya sebagai lembaga sertifikasi. Untuk peningkatan kemampuan lebih tinggi, mahasiswa diminta mencari tambahan di luar kampus atau kursus di luar kampus.

Strategi UPT Bahasa Inggris dan UPT Komputer sebagai lembaga sertifikasi, dapat mendorong tumbuhnya lembaga-lembaga kursus di sekitar kampus. Kebijakan ini akan mendorong aktivitas ekonomi masyarakat sekitar kampus. Kebijakan ini tentu membuka lapangan kerja baru bagi alumni UNIB Program Studi Bahasa Inggris dan Program Studi Teknik Informatika. Bila kebijakan ini berjalan dengan baik maka mutu, relevansi, penciptaan unggulan dan pencitraan publik dapat direngkuh sekaligus.

Menurut Fakhrurrozi Pembantu Rektor Rektor bidang akademik (2008) Revitalisasi MKWU terletak pada kegiatan perbaikan "Teaching Process" dan perbaikan terhadap isi mata kuliah. Dalam konteks kekinian, soal isi atau teori barang kali tidak banyak berubah, akan tetapi metode mengajarnya perlu ditingkatkan dan dicari metode-metode baru. Misalnya, untuk mata kuliah kewirausahaan, perlu perbaikan dalam menyesuaikan dengan tuntutan dunia kerja. Perbaikan yang ditawarkan seperti: mengajarkan pada mahasiswa dengan metode bedah kasus, presentasi, dan diskusi untuk mendapat pendalaman-pendalaman serta mensinkronisasikan dengan mata kuliah-mata kuliah lain yang menjadi "core" program studinya masing-masing yang ada di UNIB, sebagai bentuk penciptaan unggulan perguruan tinggi.

\section{Membangun Pencitraan Publik Universitas Bengkulu}

Bagaimana UNIB mendapat citra yang anggun, baik (bermutu) dari masyarakat? Salah satu upaya adalah dengan meningkatkan kualitas berkelanjutan sumber daya manusianya. Sumber daya manusia terpenting di perguruan tinggi adalah para staf pengajar atau dosen. Para dosen inilah yang didorong untuk berkembang sampai pada jenjang pendidikan dan pengalaman tertinggi, yaitu menyandang gelar akademik tertinggi (Doktor) dan Jabatan Akademik tertinggi (guru besar) di kalangan para dosen.

Sekarang bagaimana menilai Perguruan tinggi atau suatu program studi tertentu bermutu atau memenuhi standar yang telah ditentukan? Untuk itu, lihat "Akreditasi" program studi yang bersangkutan. Program Studi Manajemen Fakultas Ekonomi, Program Studi IImu Hukum dan Program Studi Bahasa Indonesia UNIB terakreditasi A artinya harkat dan nilai Program studi tersebut adalah yang terbaik (tertinggi) di Universitas Bengkulu. Para calon mahasiswa, orang tua dan dunia kerja jangan ragu atas mutu lulusan program studi tersebut yang ada di UNIB.

Sebuah perguruan tinggi dikatakan bermutu jika lebih dari 60 persen program studinya adalah akreditasinya " $A$ ", tentu di Indonesia perguruan tinggi yang kategori tersebut dapat dihitung dengan jari. Bagaimana kinerja kebijakan peningkatan mutu, relevansi, dan daya saing di Universitas Bengkulu? Ternyata pada tahun 2005 hanya ada satu program studi yang mendapat harkat nilai akreditasi $A$, yaitu program studi manajemen pada fakultas ekonomi, sisanya adalah harkat B dari program studi yang ada. Kondisi pada tahun 2008 terjadi peningkatan harkat mutu akreditasi yaitu Program studi Bahasa Indonesia dan Program studi ilmu hukum meningkat menjadi Akreditasi $A$.

Beberapa instansi seperti Bank Indonesia tidak menerima lulusan perguruan tinggi yang tidak terakreditasi A. Beberapa tahun silam, patokan mutu adalah Indek Prestasi Kumulatif (IPK) yang diperoleh selama kuliah, ternyata saat ini IPK tidak menjadi patokan utama. Artinya, perguruan tinggi secara institusional pun dijadikan tolok ukur kualitas alumninya.

Kinerja kebijakan akademik dapat dilihat pada perkembangan IPK dan lama studi mahasiswa dan masa tunggu mendapat pekerjaan. Pada tahun 2005, IPK mahasiswa adalah 3,11 dan pada tahun 2008 adalah 3,08. Lama studi mahasiswa pada tahun 2005 adalah 5 tahun 6 bulan dan pada tahun 2008 terjadi penurunan menjadi 4 tahun 6 bulan. Namun untuk menilai keberhasilan IPK perlu hati-hati. 
Ada indikasi bahwa para mahasiswa mengejar percepatan penyelesaian masa studi, sehingga mahasiswa tidak melakukan pengulangan pengambilan mata kuliah. Kemudian, lama studi mahasiswa terjadi penurunan (2008). Ini berarti kinerja kebijakan akademik dapat dikatakan berhasil karena dapat menurunkan waktu studi dan dapat meningkatkan produktivitas UNIB. Lebih lanjut, masa tunggu mendapatkan pekerjaan sulit untuk diukur secara kuantitatif. Namun, beberapa program studi terutama kependidikan dapat dipastikan masa tunggu lebih singkat. Hal ini karena kondisi di wilayah Bengkulu masih kekurangan tenaga pendidik.

Para pengelola Universitas Bengkulu saat ini harus mengupayakan bagaimana caranya memenuhi tuntutan dunia kerja yang memang meminta lulusan yang berkualitas unggul, baik secara individu maupun secara kolektif dan institusional. Sudah barang tentu jika ingin bertahan, berkembang dan mendapat citra yang baik pada dunia kerja paling tidak beberapa standar yang ditetapkan pemerintah (BAN-PT, 2007) harus dipenuhi.

Kebijakan UNIB terhadap penelitian dan pengabdian pada masyarakat diharapkan dapat mendorong partisipasi para dosen untuk melakukan riset dan uji coba serta penerapannya pada masyarakat. Kebijakan penelitian unggulan nasional dan daerah sangat diperlukan sinergi antara para pihak yang berkepentingan, agar tujuan nasional dan daerah dalam peningkatan mutu pendidikan, relevansi dan daya saing bangsa dapat berjalan secara simultan.

Oleh karena itu, setiap dosen yang berada pada program studinya masing-masing dapat mengkreasikan satu atau lebih unggulan riset dan pengabdiannya, maka terangkatlah citra UNIB. Ambil contoh, profesor dalam bidang ilmu tanah, nutrisi ternak, dan pemuliaan kopi dalam ilmu pertanian dapat bersinergi untuk membantu para petani ternak dan petani kopi dalam meningkatkan nilai tambah masing-masing.

Saat ini tidak ada lagi sekat-sekat ilmu, lintas bidang ilmu sangat diperlukan untuk mengembangkan wawasan keilmuan masing-masing. Sudah saatnya tidak mendikotomi antara bidang ilmu yang satu dengan yang lain. Ilmu bebas nilai dan dapat dipandang dari berbagai segi secara terpadu. Jika konsep sinergi ini dapat dikembangkan maka "citra" UNIB sebagai basis unggulan pengembangan sumber daya alam dan lingkungan dapat terujud dalam waktu yang tidak terlalu lama.

Universitas yang unggul dan bersaing adalah universitas yang mengetahui segmen, target, dan posisinya dalam jajaran perguruan tinggi yang ada serta Universitas yang mempunyai banyak pilihan, mengembangkan suatu unggulan tertentu, dan dengan biaya yang terjangkau oleh khalayaknya.

Untuk itu, Universitas Bengkulu harus melakukan "scanning" terhadap siapa yang telah ada dan lebih maju, siapa pasar yang hendak dituju, adakah jasa pengganti (substitusi) pendidikan tinggi, serta adakah perguruan tinggi baru yang muncul menawarkan jasa-jasa yang lebih spektakuler di masyarakat, misalnya lembaga-lembaga pendidikan keterampilan singkat yang disenangi masyarakat, karena kemampuan keterampilan para alumnusnya dinilai masyarakat baik.

Pertanyaannya adalah adakah kemauan dan itikad baik orang yang berkepentingan terhadap UNIB untuk membawa masa depan yang lebih baik sesuai dengan motto" Conveying better Future" . Harapan diletakkan pada civitas akademikanya. Oleh karena itu, bagi para doktor dan guru besar yang ada hendaknya secara serius menghasilkan karya-karya terbaiknya sehingga dalam waktu yang tidak terlalu lama unggulan dapat dicapai dan berkontribusi terhadap kegiatan ekonomi daerah.

\section{Simpulan}

Peningkatan mutu dan relevansi perguruan tinggi merupakan syarat tercapai unggulan. Banyak perguruan tinggi lalai dalam meningkatkan mutu dan relevansi, termasuk universitas Bengkulu, sehingga perguruan tinggi yang bersangkutan sulit berkompetisi di era global ini. Selajutnya, kebijakan Universitas Bengkulu dalam penciptaan unggulan mampu mendorong aktivitas ekonomi daerah secara berkelanjutan. Kemudian, ungulan dapat diciptakan berdasarkan sumber daya manusia, potensi sumber daya alam dan potensi wilayah. 


\section{Saran}

Badan Kerja Sama Perguruan Tinggi (BKS-PT) hendaknya dapat merumuskan unggulan masingmasing perguruan tinggi sesuai dengan sumber daya manusia, sumber daya alam, dan potensi wilayah masing-masing perguruan tinggi. Selajutnya, Perlu komitmen yang tinggi terhadap unggulan yang telah ditetapkan masing-masing perguruan tinggi.

\section{Pustaka Acuan}

Anonimus. 2004. Strategi Jangka Panjang Pendidikan Tinggi (HELTS) 2003-2010, DIRJEN-DIKTI, Anonimus. 2006. Universitas Bengkulu, RENSTRA-RENOP.

Anonimus. 2007. Badan Akreditasi Nasional Perguruan Tinggi, Departemen Pendidikan Nasional

Allen., Mark, (ed). 2002. The Corporate University Handbooks: Designing, Managing, and Growing a sucessful Program, New York, Amacom.

Bargh, Catherine, Peter Scott and David Smith. 1996. Coverning University: Changing the culture, Buckingham : SRHE, and Open University.

Buchari Alma, dan Ratih Hurriyati. 2008. Manajemen Corporate dan Strategi Pemasaran Jasa Pendidikan: Fokus Pada Mutu layanan Prima, Alfabeta, Bandung.

Chris, Duke. 2002. Managing The Learning University, SRHE and Open University Press, Ballmoor, Buckingham.

R. Eko Indrajit dan R. Djokopranoto. 2006. Manajemen Perguruan Tinggi Moderen, Andi Offset, Yogyakarta.

Robbin., P. Stephen. 2003. Perilaku Organisasi, PT. Indeks Kelompok Gramedia, Jakarta.

Soedijarto. 1993. Menuju Pendidkan Nasional yang Relevan dan Bermutu, Balai Pustaka, Cetakan Ke Empat. . 2008. Landasan dan Arah Pendidikan Nasional Kita, PT. Kompas Media Nusantara, Cetakan Pertama.

Sutjipto. 2000. Tantangan, Kebijakan dan Manajemen Pendidikan Tinggi: Implikasi Terhadap Transformasi IKIP Menjadi Universitas, Pidato Pengukuhan Guru Besar Universitas Negeri Jakarta.

Tampubolon Daulat P., 2001. Perguruan Tinggi Bermutu, edisi pertama, Grasindo. Tilaar, H.A.R. 2004. Manajemen Pendidikan Nasional, PT.Remaja Rosdakarya, Bandung, Warner, David and David Palfreyman (ed). 1996. Higher Education Management: The Key Element , Buckingham, SRHE and Open University Press. 